\title{
Waardetoetsing van goodwill volgens IAS 36 en FAS 142 verschillen en mogelijke implementatieaspecten
}

\section{Sander van Triest en Jeroen Weimer}

SAMENVATTING Het ten minste éénmaal per jaar toetsen van geactiveerde goodwill op waardeverlies is sinds 2001 verplicht onder de huidige regelgeving in de Verenigde Staten (FAS 142), en is sinds de invoering van de International Financial Reporting Standards (IFRS) in 2005 ook onder IAS 36 verplicht. In dit artikel beschrijven we het toetsen van goodwill op waardedaling volgens FAS 142 en IAS 36. We bespreken de stappen die in het proces doorlopen moeten worden, en we gaan in op de verschillen tussen de beide regelgevingen, zowel met betrekking tot de resultaten van de waardetoetsen als met betrekking tot mogelijke implementatieaspecten.<smiles>[CH]1C=C1</smiles>

\section{Inleiding}

Het toetsen van de waarde van activa op balansdatum behelst het vergelijken van de 'werkelijke waarde' van het actief met de boekwaarde. In dit verband is de werkelijke waarde de waarde waartegen de activa volgens de betreffende regelgeving worden getoetst. De waarde van een actief is aangetast (impaired in de terminologie van de International Accounting Standards Board (IASB) en van de Financial Accounting Standards Board (FASB)) als de werkelijke waarde kleiner is dan de boekwaarde. Het herwaarderen van activa als gevolg van een duurzame, meer dan normale waardevermindering is al langer gebruikelijk. Zie bijvoorbeeld reeds Strong en Meyer (1987) voor een analyse van bijzondere afschrijvingen. De aandacht voor toetsen van

Dr. Ir. S.P. van Triest is universitair docent bij de vakgroep Finance \& Accounting, Faculteit Bedrijf, Bestuur en Technologie, Unversiteit Twente.

Dr. Ir. J. Weimer leidt de Valuations Practice van KPMG Corporate Finance.

Dit artikel is op persoonlijke titel geschreven. de waarde van activa is echter toegenomen door veranderingen in de regelgeving. Met name nieuwe regelgeving rond goodwill kent een bijzonder belang toe aan waardetoetsing, doordat 'gewone' waardevermindering in de vorm van regelmatige afschrijving of amortisatie volgens IFRS (International Financial Reporting Standards) niet meer is toegestaan voor activa met een onbepaalbare levensduur, zoals goodwill. Daardoor is een verandering van de boekwaarde van dergelijke immateriële activa alleen mogelijk door het vergelijken van die boekwaarde met de werkelijke waarde.

In dit artikel vergelijken we de standaarden IAS 36 en FAS 142, die betrekking hebben op het verwerken en het toetsen op waardedaling van goodwill. De internationale standaard IAS 36 is sinds kort van kracht in Nederland vanwege de overgang naar IFRS per 2005. Daarnaast zijn ondernemingen met een notering in de Verenigde Staten sinds 2001 onderworpen aan de herziene Amerikaanse standaard FAS 142. We bouwen daarbij voort op een aantal bijdragen over goodwill en waardering die de afgelopen tijd in het Maandblad voor Accountancy en Bedriffseconomie zijn verschenen, met name die van Holterman (2004), Vergoossen (2004) en Camfferman en Van der Wel (2003). De bijdrage van dit artikel is een vergelijking van de twee standaarden waar Nederlandse ondernemingen mee geconfronteerd zullen worden, waarbij we zowel ingaan op verschillen in het resultaat van de toetsen, als op mogelijke implementatieaspecten.

De opbouw van dit artikel is als volgt. In paragraaf 2 beschrijven we de procedures van beide standaarden, en bespreken we de belangrijkste verschillen tussen de twee standaarden. In paragraaf 3 laten we aan de hand van een getallenvoorbeeld zien hoe de standaarden kunnen leiden tot verschillende waardedalingen van goodwill. In paragraaf 4 gaan we in op mogelijke implementatieaspecten. We baseren ons daarbij op 
literatuur die gerelateerd is aan verschillende onderdelen van de standaarden, zoals waarderingsmethodes en deelrapportages, alsmede op de praktijk van ondernemingswaardering. In paragraaf 5 sluiten we af door de implicaties voor de Nederlandse situatie te schetsen.

\section{Waardetoetsing van goodwill: procedures}

De Amerikaanse (FASB) en internationale (IASB) regelgevende instanties hebben in hun onlangs gewijzigde regelgeving gekozen voor het activeren en vervolgens jaarlijks op waardedaling toetsen van goodwill. Systematische afschrijving van immateriële activa met een onbepaalbare levensduur is niet meer toegestaan. Met de invoering van IFRS is de regelgeving van de IASB (IAS 36) verplicht in Nederland. Daarnaast zijn ondernemingen met een notering in de VS onderworpen aan FAS 142. Hoewel het basisprincipe van de twee regelgevingen gelijk is, kent de invulling en uitwerking van dit principe enkele significante verschillen die ook tot andere uitkomsten van de berekende goodwill impairment kunnen leiden. We bespreken eerst de voorgeschreven methodes, en gaan daarna in op de verschillen en de implicaties van die verschillen. De reikwijdte van beide standaarden is overigens groter, maar wij beperken ons tot die aspecten die betrekking hebben op goodwill. Zo heeft IAS 36 ook bepalingen omtrent het terugnemen van een waardedaling (impairment) van activa met een bepaalbare levensduur; dit is voor goodwill niet toegestaan. Ook FAS 142 verbiedt het terugnemen van een bijzondere waardevermindering van goodwill.

\subsection{Waardetoetsing van goodwill volgens IAS 36}

De volgende procedure wordt doorlopen volgens IAS 36:

1 Stel de kasstroomgenererende eenheden (cash generating units) vast: de kleinste afzonderlijk aan te wijzen groep van activa die kasstromen genereert die grotendeels onafhankelijk zijn van de kasstromen van andere activa (IAS 36.69).

2 Wijs activa, passiva en goodwill toe aan de eenheden. Goodwill dient toegewezen te worden aan de eenheden die synergievoordelen zullen behalen (IAS 36.80).

3 Bereken de werkelijke waarde van elke kasstroomgenererende eenheid: de werkelijke waarde is de hoogste van de fair value (reële waarde) en de gebruikswaarde, en wordt aangeduid als realiseerbare waarde (IAS 36.18).

4 Vergelijk de realiseerbare waarde met de boekwaarde. Is de boekwaarde hoger dan de realiseerbare waarde, dan dient een waardedaling verantwoord te worden (IAS 36.104).

5 Bereken de omvang van de waardedaling: de waardedaling is gelijk aan het verschil tussen de boekwaarde en de realiseerbare waarde van de kasstroomgenererende eenheid. De waardedaling loopt via de winsten verliesrekening, en wordt ten laste van de boekwaarde van de goodwill gebracht. Als de waardedaling groter is dan de boekwaarde van de goodwill dient het restant naar rato ten laste van de overige activa van de eenheid te worden gebracht (IAS 36.104).

\subsection{Waardetoetsing van goodwill volgens FAS 142}

Op grond van FAS 142 wordt de volgende procedure doorlopen:

1 Stel de verslaggevende eenheden (reporting units) vast: een verslaggevende eenheid is een segment (divisie), of een niveau onder een segment (FAS 142.30).

2 Wijs activa, passiva en goodwill toe aan de eenheden. Goodwill dient toegewezen te worden aan de eenheden die synergievoordelen zullen behalen (FAS 142.34).

3 'Stap 1': bereken de fair value van de verslaggevende eenheid. Als deze groter is dan de boekwaarde van de eenheid, dan is er geen indicatie van waardedaling en stopt de procedure. Is dat wel het geval, dan dient 'stap 2' uitgevoerd te worden (FAS 142.19).

4 'Stap 2': bereken de fair value van de goodwill. Dit begint met het berekenen van de fair value van alle materiële en immateriële activa. Daarnaast dient de fair value van niet-geactiveerde immateriële activa te worden toegevoegd. De fair value van de goodwill is de sluitpost, dus het saldo van de fair value van de verslaggevende eenheid (stap 3 ) en de fair value van alle individuele activa (FAS 142.21).

5 Bereken de omvang van de waardedaling: het verschil tussen de boekwaarde van de goodwill en fair value van de goodwill (FAS 142.20).

\subsection{Verschillen tussen IAS en FAS}

\subsubsection{Niveau van waardetoetsing}

In IAS 36 wordt expliciet aangestuurd op het identificeren van de kasstroomgenererende eenheden op het laagst mogelijke niveau van aggregatie van activa: 'IAS 36 emphasises that cash-generating units should be identified for the lowest level of aggregation possible.' (IAS 36.bcz115). Dat betekent niet noodzakelijk dat de goodwill ook op dat niveau moet worden toegewezen: IAS 36.80 laat de mogelijkheid open om goodwill aan groepen van eenheden toe te wijzen. Toch lijkt de toelichting bij de standaard te duiden op een allocatie van 
goodwill laag in de organisatie. In IAS 36.ie19 wordt het voorbeeld van een uitgever gegeven, waarbij er sprake is van zeventig tijdschrifttitels die elk als een individuele kasstroomgenererende eenheid moeten worden behandeld; een winkelketen dient de individuele winkels als eenheden te nemen, omdat een winkel in een dorpskern andere kasstromen zal genereren dan een in het centrum van een grote stad (IAS 36.ie3).

De verslaggevende eenheden die onder FAS 142 moeten worden geïdentificeerd, zijn afgeleid van de segmenten (divisies) die worden onderscheiden ten bate van deelrapportages in FAS 131. Een segment voert activiteiten uit die kunnen leiden tot kosten en opbrengsten, waarvan de resultaten regelmatig worden beoordeeld door het topmanagement, en waarvan afzonderlijke (discrete) financiële informatie beschikbaar is. De eenheden ten bate van de goodwillevaluatie zijn gelijk aan de segmenten, of aan onderdelen van die segmenten. In de toelichting op FAS 142 wordt verwezen naar de mogelijkheid van grote aantallen verslaggevende eenheden, en er wordt gesteld dat dit nadrukkelijk niet de bedoeling is: het niveau van de verslaggevende eenheid dient niet lager te zijn dan één niveau onder het segmentniveau (FAS 142.30).

\subsubsection{De 'werkelijke' waarde van een eenheid}

Het vaststellen van de werkelijke waarde van een economisch object (een individueel actief of passief, maar ook een divisie of een onderneming) is niet eenvoudig. De accountingregelgeving maakt hierbij gebruik van het concept 'fair value.' Onder FAS en IAS is de fair value van een actief de marktprijs: het bedrag waartegen een actief kan worden verkocht in een transactie tussen rationele, onafhankelijke partijen (dus niet in een situatie van gedwongen verkoop). Camfferman en Van der Wel (2003, p. 382) geven aan dat de FASB tot 1991 in plaats van 'fair value' de term 'market value' gebruikte, en dat de verandering in terminologie vooral tot stand kwam om het misverstand te voorkomen dat er geen marktwaarde kan worden bepaald in afwezigheid van een goed ontwikkelde markt voor een actief.

Bij de beoordeling van de werkelijke waarde van een eenheid wordt onder FAS 142 gekozen voor de fair value zonder meer. In geval van weinig liquide activa zal de fair value benaderd moeten worden door middel van waarderingsmethoden zoals de netto contante waarde, maar als er een goed ontwikkelde markt is voor het actief dient te worden gekozen voor de marktprijs. Deze marktprijs kan echter lager zijn dan de in paragraaf 2.1 genoemde gebruikswaarde (value in use), de waarde die het actief momenteel voor de onderneming heeft. De gebruikswaarde is gedefini- eerd als de contante waarde van toekomstige kasstromen die aan een actief ontleend kunnen worden. Zo is een tweedehands computer vaak weinig waardevol, en de marktprijs (verkoopprijs) van deze computer, en dus zijn fair value, zal waarschijnlijk onder de gebruikswaarde liggen. In het algemeen zal gelden dat veel productiemiddelen in meer of mindere mate op maat worden gemaakt (of aangepast) ten dienste van de onderneming waarin ze worden gebruikt, en dat de fair value onder de gebruikswaarde ligt. Onder IAS 36 is daarom gekozen voor de realiseerbare waarde (recoverable amount) als indicatie van de werkelijke waarde. De realiseerbare waarde van een actief is het hoogste van de fair value en de gebruikswaarde.

\subsubsection{Vaststelling van de grootte van de waardedaling}

Onder FAS 142 wordt de waarde van goodwill afzonderlijk vastgesteld als sluitpost van de fair value van de verslaggevende eenheid en de fair value van alle individuele activa (FAS 142.21). Het verschil tussen de som van de fair values van de activa en de fair value van de eenheid is de fair value van de goodwill. Onder IAS 36 wordt er geen expliciete waarde van goodwill berekend. Het verschil tussen de boekwaarde van de kasstroomgenererende eenheid en de realiseerbare waarde wordt ten laste van de boekwaarde van de goodwill gebracht. Daarmee is de goodwillpost een buffer die er voor zorgt dat de boekwaarde van een eenheid nooit hoger blijft dan de realiseerbare waarde. Nog sterker dan bij de verschillen tussen kasstroomgenererende en verslaggevende eenheid (zie paragraaf 2.3.1) is er hier sprake van een significant verschillende benadering. Onder IAS 36 kan de waardedaling groter zijn dan de boekwaarde van de goodwill, waardoor de overige activa geherwaardeerd moeten worden om de waardedaling volledig te verwerken. Onder FAS 142 kan dit nooit gebeuren, omdat daar de goodwill afzonderlijk gewaardeerd wordt, en dus maximaal tot 0 kan worden afgeschreven. Een gelijke waardedaling van goodwill onder beide regelgevingen lijkt dan ook een toevalligheid. Het zou vereisen dat de boekwaarde van alle activa precies gelijk is aan de fair value.

\subsection{Consequenties voor het resultaat van de waardetoets}

Op basis van voorgaande verschillen zijn de volgende consequenties voor het resultaat van de waardetoetsen te verwachten:

1 Meer waardedalingen onder IAS 36: omdat het niveau van de toets onder IAS 36 lager is, zullen er meer eenheden zijn die op waarde worden getoetst. Dit bete- 
kent dat de kans op het aantreffen van een waardedaling onder IAS 36 ceteris paribus groter is, omdat er meer eenheden zijn die de test afzonderlijk dienen te doorstaan.

2 Grotere waardedalingen onder FAS 142: volgens FAS 142 is de fair value het uitgangspunt voor de test. Volgens IAS 36 is dit de realiseerbare waarde, zijnde de hoogste van de fair value en de gebruikswaarde. De Europese regelgeving laat daarmee meer ruimte om bijzondere waardedalingen te voorkomen. Daarnaast is het mechanisme volgens welke de waarde van goodwill wordt berekend van invloed. De fair value van goodwill wordt volgens FAS 142 bepaald als de sluitpost van de fair value van de verslaggevende eenheid en de fair value van alle afzonderlijke activa. Tot deze activa behoren ook niet eerder geactiveerde immateriële activa, zoals merken en patenten. Indien de fair value van andere activa dan goodwill hoger ligt dan hun boekwaarde, drukt dit mechanisme de fair value van goodwill als het ware in elkaar (zie paragraaf 3). Hierdoor tendeert FAS 142 naar grotere goodwillwaardedalingen dan IAS 36.

\section{Een getallenvoorbeeld}

Met behulp van een gestileerd getallenvoorbeeld geven we verdere invulling aan de principes van waardetoetsing volgens IAS 36 en FAS 142, en laten we zien dat de verschillen in de benaderingen kunnen leiden tot verschillende waardedalingen. De beginsituatie vóór verwerking van de waardetoetsing van goodwill is weergegeven in de tabellen 1 en 2 , waarbij de beginbalans gelijk is verondersteld voor beide systemen. Het voorbeeld is gestileerd omdat in de praktijk de beginbalansen verschillen zullen laten zien. De getoonde balansopstelling, met het eigen vermogen en uitsluitend het rentedragende vreemd vermogen aan de passiefzijde van de balans, is gekozen vanuit zowel praktische als consistentieoverwegingen. In het kader van de berekening van de werkelijke waarde is de som van het eigen vermogen en het rentedragende vreemd vermogen gelijk aan de ondernemingswaarde. Bij toepassing van de discounted cash flow (DCF)-methode is de som van de contante waarde van de operationele vrije kasstromen gelijk aan deze ondernemingswaarde. Bij toepassing van de 'market multiple'-methode worden in de praktijk veelal ratio's gehanteerd waaraan de ondernemingswaarde ten grondslag ligt. Beide methoden zijn gemeengoed in de waarderingspraktijk en worden onder bepaalde omstandigheden voorgeschreven in zowel US GAAP als IFRS. Bij de waardetoets worden door deze balansopstelling op directe wijze 'appels met appels' vergeleken door het vergelijken van de ondernemingswaarde met het geïnvesteerd vermogen.

Tabel 1. Beginbalans vóór verwerking van goodwillwaardedaling.

$\begin{array}{lrlr}\text { Activa } & & & \text { Passiva } \\ \text { Goodwill } & 500 & \text { Eigen vermogen } & 400 \\ \text { Materiële vaste activa } & 80 & \text { Rentedragend vreemd vermogen } & 380 \\ \text { Immateriële activa } & 160 & & \\ \text { Netto-werkkapitaal } & 120 & & \\ \text { Voorzieningen } & \underline{-80} & & 780 \\ \text { Geïnvesteerd vermogen } & 780 & \end{array}$

Tabel 2. Winst- en verliesrekening vóór verwerking van goodwillwaardedaling.

$\begin{array}{lr}\text { Omzet } & 1100 \\ \text { Kosten van de omzet } & \mathbf{7 7 5} \\ \text { Bedrijfsresultaat } & 325 \\ \text { Rente } & \frac{25}{300} \\ \text { Winst voor belasting } & 90 \\ \text { Belasting 30\% } & 210 \\ \text { Nettowinst } & \end{array}$


Voor de goodwillverwerking volgens FAS 142 en IAS 36 dient eerst de werkelijke waarde van de eenheid te worden vastgesteld. De waarderingsmethodes van beide systemen kunnen tot verschillende uitkomsten leiden, maar in dit voorbeeld gaan we uit van een gelijk resultaat van beide waarderingen. De fair value en de realiseerbare waarde van de eenheid bedragen beide 700. Daarmee is de werkelijke waarde van de eenheid kleiner dan de boekwaarde. Onder IAS 36 leidt dit rechtstreeks tot een goodwill impairment van 80 (= $780-700)$. De nieuwe boekwaarde van de goodwill wordt daarmee $500-80=420$.

De constatering dat de werkelijke waarde van de eenheid kleiner is $(700<780)$ dan de boekwaarde leidt onder FAS 142 tot stap 2. Deze stap begint met het vaststellen van de waarde van de afzonderlijke activa. In de praktijk is dit een bewerkelijk proces, maar voor dit voorbeeld nemen we aan dat de waarden volgens tabel 3 zijn vastgesteld. In deze tabel zien we dat ook de waarde van niet-geactiveerde afzonderlijke activa dient te worden vastgesteld. Deze waarden worden hier aangenomen; in de praktijk vereist dit een waarderingsprocedure voor elk actief. Ook indien men bij het opstellen van de balans op aankoopdatum bepaalde immateriële activa niet geactiveerd heeft, dienen deze activa onder bepaalde voorwaarden toch te worden onderscheiden van de werkelijke goodwill. Aansluitend op de fair value van de eenheid wordt de fair value van de goodwill vastgesteld als de sluitpost. In tabel 3 zien we dat de fair value van de activa onder US GAAP 320 is. Omdat de fair value van de eenheid 700 is, leidt dit tot een fair value van de goodwill van 380 (= $700-320)$. Daaruit volgt dan de goodwill impairment van $120(=380-500)$.

We zien dat, uitgaande van dezelfde beginsituatie, de nettowinsten met 40 verschillen: onder FAS 142 resulteert een nettowinst van 90, tegenover een nettowinst van 130 onder IAS 36. De boekwaarde van de eenheid is onder IAS 36 gelijk aan de fair value van 700, onder FAS 142 is deze tevens 40 lager. In dit gestileerde voor-

Tabel 3. Bepaling van de fair value van de goodwill volgens FAS 142. De fair value van de goodwill is de sluitpost van de balans, en moet derhalve 380 bedragen.

$\begin{array}{lcr} & \text { boekwaarde } & \text { fair value } \\ \text { Goodwill } & 500 & ? \\ \text { Materiële vaste activa } & 80 & 90 \\ \text { Immateriële activa } & 160 & 180 \\ \text { Netto-werkkapitaal } & 120 & 120 \\ \text { Voorzieningen } & -80 & -80 \\ \text { Niet geactiveerde immateriële activa } & 0 & 10 \\ \text { (bijvoorbeeld patenten, merken, klantrelaties) } & \overline{780} & 700 \\ \text { Balanstotaal } & & \end{array}$

Tabel 4. Winst- en verliesrekeningen na verwerking van goodwillwaardedaling.

$\begin{array}{lcr} & \text { FAS 142 } & \text { IAS 36 } \\ \text { Omzet } & 1100 & 1100 \\ \text { Kosten van de omzet } & \frac{775}{325} & \frac{775}{325} \\ \text { Bedrijfsresultaat } & 120 & 80 \\ \text { Goodwillwaardedaling } & \underline{205} & 245 \\ \text { Bedrijfsresultaat na verwerking waardedaling } & 25 & 25 \\ \text { Rente } & \underline{180} & \underline{220} \\ \text { Winst voor belasting } & 90 & 90 \\ \text { Belasting 30\% } & \underline{90} & \underline{130} \\ \text { Nettowinst } & \underline{2}\end{array}$


Tabel 5. Balansen na verwerking van goodwillwaardedaling.

$\begin{array}{lcclcc} & \text { FAS 142 } & \text { IAS 36 } & \text { FAS 142 } & \text { IAS 36 } \\ \text { Goodwill } & 380 & 420 & \text { Eigen vermogen } & 280 & 320 \\ \text { Materiële vaste activa } & 80 & 80 & \text { Rentedragend vreemd vermogen } & 380 & 380 \\ \text { Immateriële activa } & 160 & 160 & & & \\ \text { Netto-werkkapitaal } & 120 & 120 & & & \\ \text { Voorzieningen } & -80 & -80 & \text { Boekwaarde } & \overline{700} \\ \text { Boekwaarde } & \overline{600} & \overline{700} & & & \end{array}$

beeld wordt het verschil van 40 veroorzaakt door waarderingsverschillen in de materiële vaste activa $(90-80=10)$ en de reeds geactiveerde immateriële vaste activa $(180-160=20)$, alsmede door de niet geactiveerde immateriële activa $(10-0=10)$.

De invulling van IAS 36 is zodanig dat goodwill als een restpost wordt gezien: als de werkelijke waarde van de entiteit kleiner is dan de boekwaarde, wordt het verschil direct gecorrigeerd op de post goodwill. Onder FAS 142 is de goodwill ook een sluitpost, maar wordt geprobeerd de fair value van de goodwill daadwerkelijk vast te stellen door alle individuele activa op fair value te waarderen en het restant als de fair value van de goodwill te beschouwen. Dit 'harmonica'mechanisme leidt tot de tendens dat waardedalingen onder FAS 142 ceteris paribus groter zullen zijn dan onder IAS 36. Immers, indien de fair value van reeds geactiveerde activa groter is dan hun boekwaarde, gaat dit ten koste van de fair value van de goodwill. Tevens draagt de fair value van niet geactiveerde immateriële activa bij aan een verlaging van de fair value van de goodwill en daarmee aan een navenante vergroting van de goodwill-impairment. De fair value van de goodwill wordt onder FAS 142 in 'stap 2' als het ware in elkaar gedrukt door de toename van de fair value van andere activa ten opzichte van hun boekwaarde.

\section{4}

\section{De regelgeving en de praktijk}

De accountingregelgeving is vaak complex, en een individuele richtlijn beslaat vele paragrafen. Desondanks is er een noodzaak tot verdere duiding van de bedoeling van de regelgever. Dat is vooral nodig bij niet eenduidige concepten als verslaggevende of kasstroomgenererende eenheid, en bij het fundamenteel problematische aspect van waardebepaling. Holterman (2004, p. 275) concludeert na bespreking van de waardebepalingsmethoden die in IAS 36 worden voorgeschreven dat de regelgeving 'meten met verschillende maten' in de hand werkt, en dat er sprake is van 'een gebrek aan heldere waarderingsrichtlijnen'. Daarop aansluitend kunnen we een aantal verschillen identificeren tussen de voorgeschreven waarderingsmethoden en de praktijk van waardering. Daarnaast biedt de literatuur een aantal aanknopingspunten om mogelijke problemen bij de implementatie op te sporen.

\subsection{Waardering in IAS 36}

1 IAS 36.55 schrijft een waarderingstoets voor die abstraheert van het meenemen van belasting in de waardeberekeningen. Bij de DCF-methode dienen kasstromen vóór belasting te worden gehanteerd en deze dienen tevens contact te worden gemaakt tegen een discontovoet voor belasting (pre-tax discount rate). Deze benadering staat in schril contrast met zowel de theorie als de waarderingspraktijk. Zo neemt het standaardwerk van Copeland et al. (2000) als indicatie voor de kasstromen het bedrijfsresultaat na belastingen ('net operating profit after tax'). Ook in de praktijk heerst de visie dat belastingeffecten expliciet dienen te worden meegenomen voor de berekening van de ondernemingswaarde. Opmerkelijk genoeg schrijft IFRS voor om de discontovoet voor belasting te berekenen door eerst op basis van een DCF-calculatie ná belasting de gebruikswaarde te berekenen, vervolgens de belasting uit de kasstromen te elimineren en ten slotte te analyseren welke discontovoet de eerder berekende gebruikswaarde na belasting als uitkomst geeft (zie IAS 36.20 en IAS 36.bcz85). De regelgever lijkt hiermee aan te geven dat het abstraheren van belasting in de waardeberekeningen niet tot verschillen met een waardeberekening inclusief belastingen zou mogen leiden. Op basis daarvan zou kunnen worden gesteld dat het hanteren van een pre-tax benadering niet bezwaarlijk is. Deze pre-tax benadering staat echter ver van de waarderingspraktijk en maakt de toepassing van de regelgeving nodeloos ingewikkeld. 
2 IAS 36.44 verbiedt het meenemen van uitbreidingsinvesteringen of herstructureringsactiviteiten bij het waarderen van een entiteit. Ook dit is niet realistisch. Het behalen van voordelen uit een samengaan van ondernemingen, dus het daadwerkelijk realiseren van de synergie, zal vaak extra investeringen en activiteiten vergen. De hoogte van de overnamesom wordt mede bepaald door de mogelijkheden die vervolginvesteringen bieden. Als de voordelen van die investeringen niet meegenomen mogen worden in de waardebepaling, leidt dit direct tot een goodwillwaardedaling (zie ook Holterman, 2004, p. 273).

\subsection{Waardering in FAS 142}

1 De invulling van 'fair value' onder FAS is anders dan de invulling van ondernemingswaarde zoals gebruikelijk in de waarderingspraktijk: '... de beste schatting door het management van de contante waarde van een activum [hoeft] niet per se gelijk te zijn aan de fair value van dat activum. Mogelijke oorzaken van zo'n verschil zijn bijvoorbeeld dat het management een ander gebruik van het activum voor ogen staat dan waar marktpartijen rekening mee houden... (Camfferman en Van der Wel, 2003, p. 382). Met andere woorden: als een onderneming bepaalde voordelen kan halen uit zijn activiteiten die anderen niet kunnen behalen, dient de waarde van die activiteiten gesteld te worden op de marktprijs, en niet op de verwachte kasstromen. Overigens zullen de specifieke voordelen die een onderneming kan behalen vaak de reden zijn waarom er goodwill wordt betaald; voor de bepaling van de waarde van de goodwill mogen die specifieke voordelen dus niet meegenomen worden.

2 Volgens FAS 142 dient de fair value van alle activa individueel te worden vastgesteld; goodwill is immers de sluitpost. Dit is een zeer intensief proces; King (2004) beschrijft vanuit een praktijkperspectief wat de problemen zijn bij het vaststellen van de fair value van individuele activa. Het is bovendien zeer de vraag of fair value wel de juiste waarde weergeeft van een actief omdat de gebruikswaarde vaak hoger zal zijn (zie ook paragraaf 2.3.2). Om deze redenen lijkt het fair valueconcept op het niveau van individuele activa (machines, computers, auto's) niet het meest geschikt.

\subsection{Indicaties voor implementatieaspecten uit de literatuur}

Met betrekking tot de keuze van het aantal eenheden waarbinnen goodwill wordt gemonitord kan er een parallel getrokken worden met de literatuur over segmentrapportage. Onder IAS 14 en FAS 131 worden ondernemingen verplicht om inzicht te geven in de afzonderlijke prestaties van de belangrijkste segmenten. De literatuur laat zien dat ondernemingen geen voorkeur hebben voor rapporteren op gedetailleerd niveau. Berger en Hann (2003) analyseren een steekproef van 2.997 ondernemingen in de VS met een omzet groter dan \$ 20 miljoen. Van deze groep rapporteert $59,8 \%$ in één segment, en slechts 3,8\% heeft vijf of meer segmenten. Andere studies (PratherKinsey en Meek, 2004; Street en Nichols, 2002) geven een gemiddeld aantal segmenten van ongeveer vier voor zeer grote ondernemingen. Het lijkt dan ook niet waarschijnlijk dat ondernemingen veel kasstroomgenererende eenheden gaan identificeren, zeker niet de vele tientallen die in de toelichting van IAS 36 ter sprake komen (zie paragraaf 2.3.1). De eerste ervaringen in de Verenigde Staten suggereren dat ondernemingen verslaggevende eenheden laten samenvallen met segmenten zoals gedefinieerd in FAS 131. De mogelijkheid om de verslaggevende eenheid een niveau onder het segment te laten vallen wordt in eerste instantie niet benut. Ook de praktijk laat zien dat de bottom-up benadering van de kasstroomgenererende eenheid niet altijd strikt lijkt te worden gehanteerd.

Het waarderingsvraagstuk lijkt nog lastiger te liggen. Meerdere studies proberen de marktwaarde van een onderneming te benaderen met behulp van een waarderingsmethode, waarbij de afwijking van de marktwaarde bepaalt of een methode beter of slechter is. Alford (1992) gebruikt een benadering met multiples voor zo'n 1500 ondernemingen. De mediaan van de voorspellingssfout ('prediction error') van de best presterende multiple die hij vindt is $24,5 \%$. Kaplan en Ruback (1995) bestuderen een bepaald type transactie waarbij ondernemingen gedetailleerde kasstroomvoorspellingen openbaar moeten maken. Op basis van die voorspelling gebruiken zij een DCF-benadering die leidt tot een gemiddelde voorspellingsfout van $21,1 \%$. Hoewel het mogelijk is dat ondernemingen op basis van hun betere kennis van de eigen activiteiten tot nauwkeurigere schattingen kunnen komen, is het duidelijk dat elke waarderingsmethode een substantiële spreiding in het resultaat zal hebben. Een waarderingsverschil van 10-20\% zal leiden tot heel andere uitkomsten van een impairment test. Deze onzekerheid is inherent aan waardering: waarde is een toekomstbegrip, en de toekomst laat zich niet vangen in regelgeving.

Vervolgens is er de vraag of gedetailleerde regelgeving leidt tot betere verslaggeving. Leiden meer voorschriften tot eenduidiger uitkomsten, met minder speelruimte voor ondernemingen? De literatuur over segment- 
rapportage biedt daar wederom een aanknopingspunt. Zowel Street en Nichols (2002) als Prather-Kinsey en Meek (2004) zetten vraagtekens bij het aantal segmenten waarover wordt gerapporteerd onder IAS 14, met name in het geval van ondernemingen die slechts één segment presenteren terwijl de bespreking in het bestuursverslag (management discussion and analysis) er op lijkt te wijzen dat ze in meerdere segmenten actief zijn. Ook het aantal posten waarover wordt gerapporteerd op segmentniveau voldoet slechts in zo'n $70 \%$ van de gevallen volgens Prather-Kinsey en Meek (2004); het gaat hier dan om relatief eenvoudige posten als omzet, resultaat en totale activa per segment. Het uitvoeren van waardetoetsen op goodwill vereist nog weer extra stappen naast het opsplitsen van bestaande posten zoals in segmentrapportage dient te gebeuren.

$\mathrm{Nu}$ zou er op gewezen kunnen worden dat IAS 14 een recente standaard is, en dat een combinatie van ervaring en beter toezicht zal leiden tot betere naleving. Inderdaad vinden Street et al. (2000) dat de al langer van kracht zijnde Amerikaanse standaard FAS 131 beter wordt nageleefd. Toch zijn ook hier kanttekeningen te plaatsen. Specifiek vinden Givoly et al. (1999) dat ondernemingen winsten lijken te verschuiven naar segmenten die actief zijn in sectoren met hoge koers/ winst-verhoudingen. Riedl (2004) laat zien dat ook op langere termijn complexe regelgeving niet noodzakelijk tot betere verslaglegging hoeft te leiden. Hij heeft gekeken naar de impact van FAS 121, over waardering van activa met een lange levensduur. Deze standaard introduceert gedetailleerde voorschriften over wanneer zo'n actief een waardetoets moet ondergaan, alsmede over de waarderingsprocedures die gevolgd moeten worden. Riedl (2004) constateert dat FAS 121 heeft geleid tot afschrijvingen (impairments) die minder goed correleren met de economische prestaties van de ondernemingen, en tot meer 'big bath' afschrijvingen. Meer regels lijken hier niet te leiden tot een hogere kwaliteit van de verslaggeving.

Een aspect van accountingregelgeving dat in de literatuur weinig aandacht krijgt, is het kostenplaatje van de regelgeving. Het moge duidelijk zijn dat het jaarlijks testen van goodwill op waardedaling kostbaarder is dan systematisch afschrijven omdat waardetoetsing een relatief groter tijdsbeslag van het management vergt indien zij deze test zelf uitvoert. Verder vereist de toets separate rapportagestructuren in het geval van IAS 36, omdat de kasstroomgenererende eenheid voor de meeste ondernemingen geen bestaand niveau is waarop managementinformatie wordt verzameld en geanalyseerd. Bindenga (2004) wijst erop dat de taak van de controlerend accountant omvangrijker wordt, en moeilijker: hij of zij zal de waarderingsprocedures, en de toekomstprognoses die er deel van uitmaken, moeten beoordelen op hun kwaliteit. Ook daaraan zijn additionele kosten verbonden. Tot slot nemen de kosten voor de onderneming toe indien het management om haar moverende redenen besluit de waarderingstoets niet zelf uit te voeren en dit aan derden uit te besteden.

\section{Conclusie}

Zowel de Amerikaanse standaard FAS 142 als de internationale standaard IAS 36 verplichten ondernemingen om goodwill ten minste éénmaal per jaar op waarde te toetsen om te beoordelen of de werkelijke waarde van de goodwill niet lager ligt dan de boekwaarde. Met behulp van een getallenvoorbeeld hebben we laten zien dat FAS 142 en IAS 36 tot verschillende resultaten leiden bij het waarderen van goodwill. Daarnaast is er een aantal implementatieaspecten naar voren gekomen. We bespreken kort de consequenties daarvan voor Nederlandse ondernemingen.

1 Naar onze mening is het twijfelachtig of Nederlandse ondernemingen de definitie van kasstroomgenererende eenheden strikt zullen volgen bij het jaarlijks waarderen van goodwill. Mede op basis van literatuuronderzoek inzake de Amerikaanse markt lijkt het waarschijnlijker dat zij in eerste instantie aansluiting zullen zoeken bij de reeds bestaande rapportagestructuren voor de bepaling van het niveau waarop de toets wordt uitgevoerd.

2 De voorgeschreven waarderingsmethoden laten in beginsel de ruimte tot een relatief grote bandbreedte van de waardedaling van goodwill, zeker onder IAS 36. Deze onzekerheid zou mogelijk beperkt kunnen worden door meer gedetailleerde regelgeving, maar blijft inherent aan het waarderen van economische entiteiten. Het resultaat van een waardetoets is derhalve altijd subjectief.

3 Er zullen meer kosten verbonden zijn aan het jaarlijks toetsen van de waarde van goodwill dan aan het (systematisch of in één keer) afschrijven van goodwill door het vereiste additionele tijdsbeslag van het management, de hogere kosten van de accountantscontrole en als gevolg van de eventuele uitvoering van de test door een derde partij. Dit geldt nog sterker voor FAS 142, omdat daar niet alleen de fair value van de verslaggevende eenheden moet worden bepaald, maar ook die van de afzonderlijke activa. 
4 Een aantal van de richtlijnen die in het kader van de goodwillregelgeving zijn uitgevaardigd, sluit niet aan op de waarderingspraktijk. Dit geldt met name voor het vereiste abstraheren van belasting en de restricties op het meenemen van uitbreidingsinvesteringen onder IAS 36. Dit bemoeilijkt het naleven van de regelgeving, en doet daarnaast de vraag rijzen of het resultaat van de waardering wel overeenkomt met de werkelijke waarde.

De praktijk zal moeten uitwijzen of de nieuwe regelgeving zal bijdragen aan een betere verslaggeving over goodwill. Onze inschatting is dat een analyse van toekomstige jaarverslagen van Nederlandse ondernemingen zal illustreren dat IAS 36 in haar huidige vorm ruimte laat voor een grote bandbreedte van goodwillwaardedalingen, en dat verschillen met FAS 142 zullen blijven bestaan, zelfs bij een gelijke waardering van de ondernemingsprestaties.

\section{Literatuur}

Alford, A.W., (1992), The effect of the set of comparable firms on the accuracy of the price-earnings valuation method, in: Journal of Accounting Research, vol. 30, no. 1, pp. 94-108.

Berger, P.G. en R. Hann, (2003), The impact of SFAS no. 131 on information and monitoring, in: Journal of Accounting Research, vol. 41, no. 2, pp. 163-223.

Bindenga, A.J., (2004), Impairment en de controlerend accountant, in: Maandblad voor Accountancy en Bedrijfseconomie, vol. 76, no. 6, juni, pp. 277-281.

Camfferman, C. en F. van der Wel, (2003), Reële waarde in de regelgeving, in: Maandblad voor Accountancy en Bedrijfseconomie, vol. 75, no. 9, september, pp. 379-386.

Copeland, T., T. Koller en J. Murrin, (2000), Valuation: measuring and managing the value of companies, 3rd ed., John Wiley, New York.

Financial Accounting Standards Board, (1997), Statement of financial accounting standards no. 131: Disclosures about segments of an enterprise and related information, Norwalk.

Financial Accounting Standards Board, (2001), Statement of financial accounting standards no. 142: Goodwill and other intangible assets, Norwalk.

Givoly, D., C. Hayn en J. D'Souza, (1999), Measurement errors and information content of segment reporting, in: Review of Accounting Studies, vol. 4, pp. 15-43.

Holterman, W.G.M., (2004), Waardebepaling in het kader van de goodwill impairment-test, in: Maandblad voor Accountancy en Bedrijfseconomie, vol. 76, no. 6, juni, pp. 269-276

International Accounting Standards Board, (2004), IAS 36 Impairment of assets and IAS 38 Intangible assets, Londen.

Kaplan, S.N. en R.S. Ruback, (1995), The valuation of cash flow forecasts: an empirical analysis, Journal of Finance, vol. 50, no. 4, pp. 1059-1093.

King, A.M., (2004), Go figure, Strategic Finance, vol. 86, July, pp. 36-40.

Prather-Kinsey, J. en G.K. Meek, (2004), The effect of revised IAS 14 on segment reporting by IAS companies, in: European Accounting Review, vol. 13, no. 2, pp. 213-234.

Riedl, E.J., (2004), An examination of long-lived asset impairments, in: Accounting Review, vol. 79, no. 3, pp. 823-852.

Street, D.L. en N.B. Nichols, (2002), LOB and geographic segment disclosures: an analysis of the impact of IAS 14 revised, in: Journal of International Accounting, Auditing \& Taxation, vol. 11, pp. 91-113.

Street, D.L., N.B. Nichols en S.J. Gray, (2000), Segment disclosures under SFAS no. 131: has business segment reporting improved?, in: Accounting Horizons, vol. 14, no. 3, pp. 259-285.

Strong, J.S. en J.R. Meyer, (1987), Asset writedowns: managerial incentives and security returns, in: Journal of Finance, vol. 42, no. 3, pp. 643-661. Vergoossen, R.G.A., (2004), Bijzondere waardevermindering van vaste activa in de regelgeving, in: Maandblad voor Accountancy en Bedrijfseconomie, vol. 76, no. 6, juni, pp. 261-268. 